NBER WORKING PAPER SERIES

\title{
PATENTS AS QUALITY SIGNALS? THE IMPLICATIONS FOR FINANCING CONSTRAINTS ON R\&D
}

Dirk Czarnitzki

Bronwyn H. Hall

Hanna Hottenrott

Working Paper 19947

http://www.nber.org/papers/w19947

\author{
NATIONAL BUREAU OF ECONOMIC RESEARCH \\ 1050 Massachusetts Avenue \\ Cambridge, MA 02138 \\ February 2014
}

The authors thank Thorsten Doherr for help with retrieving the patent data and participants at the CONCORDi 2013 (Seville, Spain) for helpful comments. Hottenrott appreciated research funding from the Flemish Science Foundation (FWO). The views expressed herein are those of the authors and do not necessarily reflect the views of the National Bureau of Economic Research.

At least one co-author has disclosed a financial relationship of potential relevance for this research. Further information is available online at http://www.nber.org/papers/w19947.ack

NBER working papers are circulated for discussion and comment purposes. They have not been peerreviewed or been subject to the review by the NBER Board of Directors that accompanies official NBER publications.

(C) 2014 by Dirk Czarnitzki, Bronwyn H. Hall, and Hanna Hottenrott. All rights reserved. Short sections of text, not to exceed two paragraphs, may be quoted without explicit permission provided that full credit, including $(\mathcal{C}$ notice, is given to the source. 
Patents as Quality Signals? The Implications for Financing Constraints on R\&D

Dirk Czarnitzki, Bronwyn H. Hall, and Hanna Hottenrott

NBER Working Paper No. 19947

February 2014, Revised February 2015

JEL No. G32,O31,O32,O38

\begin{abstract}
$\underline{\text { ABSTRACT }}$
Information about the success of a new technology is usually held asymmetrically between the research and development (R\&D)-performing firm and potential lenders and investors. This raises the cost of capital for financing R\&D externally, resulting in financing constraints on R\&D especially for firms with limited internal resources. Previous literature provided evidence for start-up firms on the role of patents as signals to investors, in particular to Venture Capitalists. This study adds to previous insights by studying the effects of firms' patenting activity on the degree of financing constraints on R\&D for a panel of established firms. The results show that patents do indeed attenuate financing constraints for small firms where information asymmetries may be particularly high and collateral value is low. Larger firms are not only less subject to financing constraints, but also do not seem to benefit from a patent quality signal.
\end{abstract}

Dirk Czarnitzki

K.U. Leuven

Department of Managerial Economics

Strategy and Innovation

Naamsestraat 69, 3000 Leuven

Belgium

dirk.czarnitzki@econ.kuleuven.ac.be

Bronwyn H. Hall

Department of Economics

549 Evans Hall

UC Berkeley

Berkeley, CA 94720-3880

and NBER

bhhall@nber.org
Hanna Hottenrott

Düsseldorf Institute for Competition Economics

(DICE)

Heinrich Heine University

Universitätsstrasse 1

40225 Düsseldorf

Germany

hottenrott@dice.hhu.de 


\section{Introduction}

A view widely held by economists and entrepreneurs is that investments in research and development (R\&D) are discouraged by imperfections in capital markets. The main reason is that information about the success of a new technology is usually held asymmetrically between the R\&D performer and potential lenders and investors, making it difficult for these outsiders to judge the R\&D-performing firms' quality (Arrow 1962). This raises the cost of external capital and makes it in some cases impossible to obtain financing for projects that would have a positive expected net present value if normal interest rates or the cost of internal funds (if available) were used to estimate value. In the light of this phenomenon, an increasing number of academic studies have attempted to understand, identify, and explain the occurrence of financing constraints for R\&D and innovation. ${ }^{1}$

Drawing on the concept of job market signals (Spence 1973), several studies have suggested that patents provide signals to external investors that mitigate such financing constraints. As lenders may be able to derive probabilities for the success of R\&D-active firms across certain industries, but usually have difficulties assessing the value of R\&D activities of individual firms, the role of quality signals thus lies in their potential to reduce information asymmetries by providing a "sorting mechanism”. Signals thus help outsiders to derive expectations about the quality of the firm that cannot be directly observed, such as $R \& D$ success. Due to the inherent characteristics of the $R \& D$ process, when evaluating R\&D-intensive firms external lenders and investors therefore usually have to rely on observable firm characteristics which are presumably correlated with characteristics directly related to the R\&D project(s) and their success, which are not easily observable. Long (2002) was among the first to argue that patents are an effective instrument for reducing information asymmetries between the patenting firm and outside investors. Patents have properties that may make them ideal candidates as proxies for the quality assessment of R\&D-active firms: they are costly to obtain, easily observable and verifiable by outsiders. If lenders believe that patents correlate with other, less easily observable firm characteristics which are not necessarily directly

\footnotetext{
${ }^{1}$ See Hubbard (1998), Hall and Lerner (2010) and Czarnitzki and Hottenrott (2010) for surveys of the literature.
} 
related to the inventions, patent applications or grants may function as signals for otherwise unobservable or difficult-to-measure attributes, such as knowledge capital or the productivity of R\&D spending. Moreover, the patenting process may help to reveal information about technological discoveries and their potential value that otherwise would be more difficult to convey to lenders and investors. The ability to convey information credibly to outsiders at relatively low cost may therefore be a highly valuable certification function of patents (Long, 2002, Arora et al. 2001).

Previous research that has studied the signaling value of patents has focused mainly on start-up firms in high-tech industries. This literature usually finds a positive relationship between patents and Venture Capital (VC) financing (e.g. MacMillan 1985; Baum and Silverman 2004; Mann and Sager 2007, Haeussler et al. 2009; Conti et al. 2013, Hsu and Ziedonis 2013). While the evidence for patents as a quality signal for attracting VC financing concludes that they do indeed function that way, the evidence for the impact of patents on obtaining later stage financing, such as for the success of initial public offerings (IPOs), is rather mixed (Deeds et al. 1997; Stuart et al. 1999; Heeley et al. 2007).

This paper contributes to the existing literature by providing panel data evidence for a large sample of established, R\&D-active firms. To our knowledge, it is the first to look at established firms rather than start-ups. Recent research stressed that not only firms’ age (young firms are usually also small), but also size among older firms matters for access to financing (Czarnitzki and Hottenrott 2011a; Fort et al. 2013). The following analysis will therefore study the certification effect of patents taking size heterogeneity among the firms into account. Moreover, it is among the first papers to study the relationship using patents filed at the European Patent Office rather than the US Patent and Trademark Office. We further employ a methodology that allows studying financing constraints in the market for bank finance as bank loans constitute the major external financing source for firms in most European countries.

More precisely, the study adds to previous research on the topic by investigating a large sample of R\&D-active firms from the Flemish part of the OECD R\&D survey in a broad range of industries comprising both small and large firms. We estimate panel data models for the period 2000 to 2009 that allow us to control for unobserved firmspecific effects. However, due to the unbalanced nature of the panel and the fact that 
the dependent variable is censored at zero, we are unable to estimate fully dynamic panel data models.

The results show that patents indeed attenuate financing constraints. This holds for the patent stock of the firms as well as for recently filed patents. As patents may be particularly useful in reducing information asymmetries between firms and lenders when information asymmetries are large and when alternative ways of achieving credibility are limited, we expect small firms to benefit more from patent signals than larger ones. In line with these expectations, we find the effects to hold only for small firms with less than 50 employees. Larger firms are not only less subject to financing constraints in the first place, but also do not seem to benefit from a patent quality signal. We do not find any corresponding effect for young firms versus old firms, but this may be due to the fact that our sample includes only established young firms (those older than 5 years old) and not startups.

This article proceeds as follows. Section 2 outlines the motivation for this research and briefly summarizes related research. Section 3 sets out the conceptual framework of our analysis and section 4 describes the data. The econometric set-up, our model specifications and the results are described in section 5 . Section 6 concludes.

\section{Capital Market Imperfections and the Signaling Value of Patents}

\subsection{The role of internal finance for $R \& D$}

Generally a firm is considered to be financially constrained if it cannot carry out its R\&D activities at desired scale and scope due to a lack of financing availability or a very high cost of financing. Unlike most investment in tangible goods, R\&D projects are characterized by high and usually firm specific investments, on the one hand, and low collateral value, on the other hand. Before willing to grant a loan, banks usually require some degree of collateral value. Especially small, R\&D-active firms may fail to provide sufficient collateral value to lenders that would back potential loans. Additionally, information asymmetries between the R\&D-active firm and lenders adversely affect financing conditions. Information asymmetries may be particularly severe in case of small firms for which credibly conveying information regarding their technological capabilities and overall creditworthiness is hard. As argued by Berger and Udell (1998), “unlike large firms, small firms do not enter into contracts that are 
publicly visible or widely reported in the press - contracts with their labor force, their suppliers, and their customers are generally kept private”. Moreover, small firms usually do not issue traded securities that are continuously priced in public markets and often do not have audited financial statements that are available to providers of outside finance.

Consequently, it is relatively more expensive for lenders to collect information on small firms, who usually apply for loans of relatively small amounts, where cost is measured by screening costs per borrowed or invested Euro. Likewise, small firms face a relatively high cost of providing information to lenders as doing so requires scarce human, financial and time resources. As a result, small firms may have larger difficulties to credibly convey their quality to outsiders than larger firms.

If instead of detailed assessment, lenders consider average project quality in the market to assess a firm's R\&D quality, this may result in a "lemon’s premium” for above-average projects increasing financing costs even for the most promising firms (Leland and Pyle, 1977). Constrained firms therefore (have to) rely to a larger extent on internal resources when financing their R\&D than firms that mainly invest in capital goods (Hall 1992; Himmelberg and Peterson 1994; Harhoff 1998; Bougheas et al. 2003; Levitas and McFayden 2009; Czarnitzki and Hottenrott 2011a). This fact constrains $R \& D$ projects for firms whose internal financial sources are limited and whose innovation potential is high (Brown et al. 2012; Borisova and Brown 2013; Czarnitzki and Hottenrott 2011b, Hottenrott and Peters 2012). Not surprisingly, earlier empirical evidence supported the view that small firms in particular encounter difficulties financing $\mathrm{R} \& \mathrm{D}$ leading to delayed, canceled or postponed projects (Carpenter and Petersen 2006; Schneider and Veugelers 2010; Czarnitzki and Hottenrott 2011a). ${ }^{2}$ In line with these previous insights, we thus hypothesize that

\footnotetext{
${ }^{2}$ One might think that this lack of access to debt would lead to firms issuing equity. However, small firms may be particularly reluctant to issue equity, even if this excludes them from certain projects. In Belgium, as in many other European countries, raising equity for financing investment projects generally appears to be disfavored and only relatively few firms are listed at stock exchanges. Particularly small, family owned firms view issuing of new equity as not particularly desirable as it dilutes their ownership position. For example, Deloof and Jegers (1999) point out there were no public issues of a straight bond by a Belgian company between 1990 and 1995. Borrowing from banks is the most common form of raising funds for investment besides internal sources such as intra-group loans (see for example Deloof 1998).
} 
Hypothesis 1: Small R\&D-active firms are more likely to be financially constrained in their $R \& D$ investment than larger $R \& D$-active firms. Thus, small firms' $R \& D$ investment should be more sensitive to internal liquidity than that of larger firms.

\subsection{The role of patents}

If firms seek access to external financing while engaged in complex $R \& D$ projects that require a high degree of specialized skills to understand the technological details, lenders and investors usually have to rely on observable firm characteristics which are presumably correlated with properties that are not easily observable such as those directly related to the firms' R\&D project(s). Because it can be costly and difficult for potential lenders to assess the value and thus the creditworthiness of a firm, quality signals may be used to reduce cost and effort devoted to quality assessment of the firms. Signals may provide a "sorting mechanism" based on an easily observable attribute that allows deriving expectations about qualities of the firm that are not immediately observable.

Long (2002) argued that patents are effective for reducing information asymmetries between the patenting firm and outside investors. She distinguished "the simple view of intellectual property rights” that regards patents as an exchange of information for compensation in the form of protection, from a broader view that considers patents also as a tool to credibly convey information about the underlying innovation. The argument is based on the fact that patents have properties that may make them good and readily available proxies for the quality assessment of R\&D-active firms. First, patents are costly to obtain (administrative and attorneys' fees in addition to the R\&D that is often needed to come up with a patentable invention), ${ }^{3}$ and are easily observable and verifiable for outsiders. Myers and Majluf (1984) stressed the importance of supplying a "verifiable detail" to convey information. Patents are publicly available documents that minimize information costs for potential lenders and investors and since penalties for intentionally misrepresenting information in a patent application are severe, outsiders know that the information contained in a patent has some credibility (Long 2002).

\footnotetext{
${ }^{3}$ Note that inventions do not always require systematic R\&D upfront.
} 
Second, if lenders assume that patents correlate with difficult-to-measure firm characteristics that are not necessarily directly related to the firms' patented inventions, patents may still be a useful signal. For instance, patents provide information about the firms' ability to perform valuable research as patents measure the outcome of past R\&D and thus “advertise” the firms' innovative capabilities. For an invention to be patentable, it must be new, industrially applicable and involve an inventive step. These requirements and the fact that patent applications need to be approved by the patent office through a certification process, suggest that possessing a patent is the result of successful previous $R \& D$, hence signaling the general $R \& D$ competencies of the firm (Stuart et al. 1999). ${ }^{4}$ Henderson and Cockburn (1994), for example, used patent counts to measure the research competencies of firms in the pharmaceutical industry and Harhoff (2009) argues that patents may signal the quality of the firms’ R\&D staff and its ability to handle intellectual property rights.

Moreover, market value studies typically find that both R\&D expenditures and patent stocks correlate positively with firms' market value, and that patent stocks add information on the value of firms' knowledge assets beyond R\&D stocks (Hall 2000; Hall et al. 2005; Czarnitzki et al. 2006). Thus, lenders may use patent counts to extrapolate the future value of the firm. In addition, firms owning a patent experience a larger growth rate and higher productivity than firms not owning a patent and this relationship has been shown to be stronger for small patentees in the UK (Helmers and Rogers 2011; Hall et al. 2013).

Levitas and McFayden (2009) note that patents raise the prospects of future cash flows and as patents protect firms - at least to some extent - against competition, they may be expected to earn higher profit margins in the future. Moreover, since patents facilitate the licensing of technology, patents may signal additional returns to the patented technologies (e.g. Kulatilaka and Lihui 2006).

\footnotetext{
${ }^{4}$ The threshold for patentability in the United States is considered by some observers to be low, especially in IT-related sectors (Jaffe and Lerner, 2004), which casts doubts on the signaling value of patents. The threshold is considered to be higher in Europe (van Pottelsberghe de la Potterie 2011). In addition, Haeussler et al. (2009) argue that European patents are approximately 5 to 10 times more expensive than U.S. patents. However this is a controversial area, and there exist dissenters (Christie et al. 2013). Hall et al. (2007) find that the valuation of US and EPO patents in US and European firms is fairly similar.
} 
Almost more important than the profitability of the firm for lenders is the survival of the firm. The high risk of bankruptcy is one reason why small and young firms face difficulties in raising external financing. Cockburn and Wagner (2007) show that possessing patents is positively correlated with the survival of the firm and Mann and Sager (2007) also find a positive relationship between patenting activity and several success measures among which survival.

From the perspective of the firm, a reluctance to disclose innovation-related information to outsiders because of fear of imitation by competitors may exist (Bhattacharya and Ritter 1983; Anton and Yao, 1998), so that one would expect rational firms to seek patent protection only if the expected returns from the patent outweigh the costs of disclosing the information. If patents, however, have some signaling value, firms may be willing to disclose the information on their inventions in patent applications not only in exchange for being able to exclude others from using the information in certain ways, but also in order to reduce informational asymmetries between themselves and outsiders. Being aware of such a signaling value, firms may apply for patents to signal information about themselves and their $R \& D$ that would be more expensive or even impossible, or less credible when revealed in other contexts. This may explain why firms (and especially small and young companies) patent even when the need to exclude others is not important because of high cost of imitation. Moreover, because of the comparatively higher burden of obtaining a patent for small firms, it provides an even stronger patent signal to external parties. Finally, patents may also signal some salvage value that will be available if the firm goes bankrupt. However, it can be argued that the true collateral value is very difficult to assess and that therefore the signal stems more from the fact that patents make research output "as tangible as it gets".

Based on these arguments, we hypothesize that patents have some signaling value that helps the firm obtain finance:

Hypothesis 2: Firms' past patenting activities alleviate financing constraints.

We will measure the presence of these constraints via the sensitivity of firms' R\&D investment to the availability of internal funds. Additionally, the previous considerations lead us to hypothesize that small firms benefit more from the existence of patent signals than larger firms. Thus, we further hypothesize the following: 
Hypothesis 3: Firms' past patenting activities are more important for alleviating financing constraints for small firms' than for larger firms.

A crucial feature of a patent is that it signals hidden attributes of the firm that lenders assume will increase the value of the firm or may make it likely that the firm will repay its debt, even if the value gain is not directly related to the patent. For example, having a patent may constitute a competitive advantage through being a first-mover in the industry (Bessen and Maskin 2009). According to Long (2002) this might explain why industries in which competitive advantage in product markets is often derived from being a first mover, such as semiconductors and information technology, are also among the industries in which patenting is most active (Hall and Ziedonis 2001). Further, it might explain why small firms, which usually face greater informational asymmetries in capital markets than large firms, tend to patent relatively more intensely (in comparison to their R\&D) than large firms, even though they may enforce their patents less (Griliches et al. 1987; Mansfield 1986). ${ }^{5}$

Importantly, Lemley (2000) argues that venture capitalists use patent applications as evidence that the company is well managed, is at a certain stage in development, and has defined and carved out a market niche, rather than attributing a certain value to the patent itself. Similarly, patents may simply indicate the firm's confidence in its research which may not be necessarily related to the relevance of the technology for future inventions. Thus, if patents constitute a quality signal, we expect that

Hypothesis 4: The signaling value of a patent application is related to its existence, but unot related to the covered technology's ex-post value.

\subsection{Empirical evidence}

Since the work of MacMillan (1985) patents have been recognized as a relevant selection criterion for Venture Capital (VC) investors. A considerable number of studies has since supported the hypothesis of a positive relationship between the patent stock of high-tech start-ups and the amount of VC funding received.

\footnotetext{
${ }^{5}$ This argument applies to small producing firms. There is other evidence that small non-producing firms that specialize in acquiring patents litigate more than other firms, at least in the United States. See Lanjouw and Schankerman (2004), inter alia.
} 
Hall and Ziedonis (2001) interview executives in the US semiconductor industry and find that they consider patent rights to be of significant importance in attracting VC funding. Similarly, Baum and Silverman (2004) show a positive relationship between patent applications at the US Patent Office and VC financing. However, they conclude that the importance of patents in this regard varies across industries. Mann and Sager (2007) analyze the relationship between patenting of software start-up firms and the progress of those firms through the VC cycle. They find significant and robust positive correlations between patenting and the number of financing rounds, total investment, as well as the receipt of late stage financing. Interestingly, they observe that the effect of patents depends less on the size of the patent portfolio than on the firm's receipt of at least one patent.

Hsu and Ziedonis (2013) argue that patents can increase the perception about the value of start-ups and that new entrepreneurial firms benefit most in early stages of financing when technological uncertainty is high and alternative means for conveying quality to outsiders is lacking. In particular, they find that venture-backed semiconductor start-ups with a higher patent application stock than others are more likely to attract initial funding from a prominent venture capitalist. For start-ups by founders without prior success in securing initial funds from prominent VCs, patents are even more influential. Moreover, they find patents to induce steeper valuation adjustments in earlier rounds of VC financing.

Using a sample of German and British biotechnology companies, Haeussler et al. (2009) find that VC funding happens earlier when patent applications are present. Levitas and McFayden (2009) suggest that patents signal the firms' invention and innovation competencies and facilitate access to external financing as they observe that patent owning firms seem to rely less on accumulating large cash holdings to fund their (future) R\&D projects. Most recently, Conti, Thursby and Rothaermel (2013) examine a sample of start-up firms in the Georgia Institute of Technology new firm incubator and find that those with patents obtain more external financing; the authors conclude that patents serve as a signal for venture capitalists. Hoenen et al. (2014), however, find for U.S.-based biotechnology firms that patent applications are positively associated with first-round, but not with second-round VC financing. Conti, Thursby and Thursby (2013) concluded that patents serve to attract new investors and 
are intended for that purpose by Israeli start-up firms. This signal, however, is only effective for venture capitalists, but not for private investors.

While previous research usually finds a positive relationship between patents and VC financing, evidence for later stage financing is rather ambiguous. Examining the IPO performance of biotechnology start-ups, Deeds et al. (1997) find no effects of patents on the amounts raised in an IPO and conclude that patents may only be "noisy" signals that do not really affect the expectations of public investors. Stuart et al. (1999) observe that biotechnology start-ups advertise their patent filings when aiming at initial public offerings (IPOs) although these authors also find that patents have minimal effect on market value of new biotechnology listings. Likewise, Heeley et al. (2007) find contradictory results concluding that patents can serve as signaling devices in sectors such as biopharmaceuticals and chemicals, while they find no such evidence for information technology (IT) firms.

The motivation for the following study is thus based on two aspects that have not been addressed by previous research. First, this study is the first to use panel data evidence for a large sample of established, R\&D-active firms. Recent research on financing constraints for R\&D reported evidence for such constraints not only for young, start-up firms, but also for more established firms (Czarnitzki and Hottenrott 2011a,b; Czarnitzki et al. 2011; Hottenrott and Peters 2012; Mina et al. 2013; Lahr and Mina 2013). However, no study examines the role of patents for mitigating financing constraints for these firms. Second, the following study is among the first to look at this question using patents filed at the European Patent Office.

\section{Conceptual Framework}

Following on the seminal work of Fazzari et al. (1988), many econometric studies have approached the detection of financing constraints by comparing different groups of firms in terms of their investments' sensitivity to internal financing. While this approach was initially applied for any type of investment, later studies have adopted the methodology analogously to investment in R\&D (e.g., Hall 1992; Himmelberg and Peterson, 1994). For the group of supposedly unconstrained firms, R\&D spending should not be as sensitive to the availability of internal funds as the R\&D of constrained firms, as the former group is able to raise financing externally. Recent research further stressed the importance of $R \& D$ smoothing through cash holdings 
especially for firms that are most likely to face financing frictions (Brown and Peterson 2011; Brown et al. 2012). In line with this methodology, we use a standard empirical model of R\&D investment sensitivity to internal liquidity and examine how the estimates of this model vary across firms of different sizes. We measure internal liquidity by the firms' working capital including cash holdings. To explore the role of firm size, we distinguish between large and small firms where "small" is defined using the European Commission definition, namely that the firm has fewer than 50 employees, and estimate separate equations for small and large firms' investment to identify differences in the reliance of firms on internal funds, on the one hand, and difference in the effects of firms patenting activity on access to external financing, on the other. We expect a positive relationship between firms' liquidity and the firms' expenditures in $R \& D$ and we expect this relationship to be stronger for the small firms, as suggested by hypothesis (1).

If patents serve as a quality signal the firms' stocks of patents (or the number of preperiod patent applications) should reduce the firms' reliance on internal funds for their R\&D investments. Harhoff (2009) argues that patents do not necessarily have to be granted yet in order to work as a signal as even patent applications reveal information and require money and time. Hence, we use patent applications rather than granted patents in the subsequent analysis. We expect that the interaction term between patent applications and internal funding is negative, (partially) off-setting the positive effect of internal liquidity.

\section{Data}

The following analysis uses a unique database that we constructed based on several sources: the Flemish R\&D survey, the OECD/EPO patent citations database, and the Bureau van Dijk BEL-FIRST database. The proposed analysis requires nonanonymized firm level data including variables such as R\&D collected over a long period of time as well as financial information for small firms that are not subject to strict publication rules for accounting data. Although such data is available for other countries, it is usually not possible for external researchers to access these data in the non-anonymized form that allows search by company names in a patent database. For the present paper, we had such data available and we were able to link firms and 
patents at the firm level using text-field string matching based on firms' names and addresses.

Information on firms' R\&D-related activities comes from the Flemish part of the OECD R\&D survey. This survey is harmonized across OECD countries and is conducted every second year in order to compose the OECD Main Science and Technology Indicators. The sampling population from which the survey sample is drawn targets all R\&D-active companies in Flanders. Our analysis is based on repeated cross sections that form an unbalanced panel from five consecutive waves of the R\&D survey covering the period from 2000 until 2009. Each wave provides information at the firm level for two consecutive years. The definition of research and development used in the survey is based on the definition of the OECD Frascati Manual (1993, 2002) which frames the methodology for collecting and using statistics about R\&D in OECD countries.

Patent information comes from a database issued by the European Patent Office (EPO), the “OECD/EPO patent citations database” (Webb et al., 2005). This database covers all patents applied for at the EPO since its foundation in 1978 as well as all patents applied for under the Patent Cooperation Treaty (PCT) in which the EPO is designated, so-called "Euro-PCT applications". Additionally, information from the Belgian patent office was used to include information about patents filed in Belgium only. Patent data is available as a time series from 1978 until the end of 2011.

The accounting and balance sheet data for our firms stems from the BELFIRST database provided by Bureau van Dijk. BELFIRST is a comprehensive database that contains information on about 1.2 million active and non-active Belgian companies. Approximately half of the companies have financial account information; the remainders are generally individuals (sole traders).

Our sample comprises firms that invested at least once in R\&D during the panel period and are observed at least twice during that time. We require two years of data since we estimate simple panel data models that control for unobserved heterogeneity. On average, we observe each firm about 4 times in our panel. After eliminating data with missing values in the variables of interest and requiring the firms to be observed at least twice during the sample period, our final unbalanced panel consists of 4,309 unique firm-year observations referring to 1,135 different firms active in a broad 
range of industries. Table A1 in the appendix provides details on the distribution of firms across industries.

\subsection{Variables}

Firms’ R\&D expenditures (more precisely, firms’ $R \& D$ intensity measured as the ratio of $R \& D$ spending to tangible capital) serve as the dependent variable in the following analysis $(R \& D)$. We derive indicators for the firms' capital structure from balance sheet information. ${ }^{6}$ The firms' stock of working capital serves as a measure of operating liquidity. As suggested by Hall and Kruiniker (1995), using working capital instead of cash flow as a measure of firms' liquidity is preferable, because it is a better indicator of the funds available for investment. ${ }^{7}$ Although working capital is affected by cash flow, working capital is a more precise liquidity indicator when it comes to investment decisions as it also includes not only cash but also values that can relatively easily be converted into cash; in short, it is a stock rather than a flow. Working capital (WCAP) is defined as net short-term assets, that is, the difference between current assets and current liabilities of a firm. In this study, we use a somewhat stricter measure that is to a high degree comparable across firms in our sample and not biased by accounting options, computing working capital WCAP as cash + inventories + accounts receivable - accounts payable. ${ }^{8}$ Other short term assets (other current assets, prepaid expenses, and deferred charges) and short term liabilities (other short term debt and other creditors) are not included. The higher the working capital the more secure is a firm's liquidity and accordingly its financial flexibility. This variable can take positive or negative values. Positive working capital means that short-term liabilities are covered by current assets whereas negative working capital indicates that a firm's current assets are not sufficient to cover its current liabilities.

\footnotetext{
${ }^{6}$ These accounts follow the Belgian GAAP on an annual basis.

${ }^{7}$ The appropriateness of cash flow as an indicator for financial liquidity and the interpretation of the sensitivity of R\&D investment to changes in cash flow has been criticized in the literature (Hao and Jaffe 1993; Fazzari and Petersen 1993; Kaplan and Zingales 1997, 2000). Especially for large firms, cash flow levels may be determined by accounting practice as well as by dividend policies (Jensen and Meckling 1976; Jensen 1986).

${ }^{8}$ Accounts receivable and accounts payable are termed Trade Debtors and Trade Creditors in the data source. Inventories are called Stocks.
} 
As an indicator of the state of the firm's balance sheet and its access to the credit market, we use the ratio of long term debt (consisting of all non-current liabilities payable later than one year) to tangible assets of the firm. ${ }^{9}$ For this variable, we use a two period lag as debt is measured at the end of the year $t-2$, so that its visibility to potential lenders is effective in $t-1$. We calculate the firms' debt-to-tangible assets ratios (DEBTRATIO) rather than debt-to-equity ratios as the former type is more meaningful in reflecting the firms' liabilities relative to the firms' collateral value. Thus, as common in the literature, we scale the dependent variable as well as WCAP and DEBT by firm assets (see e.g. Fazzari et al. 1988; Fazzari and Petersen 1993; Harhoff 1998). We use tangible assets (K) from the firm accounts, which excludes intangible assets, financial assets, and current assets.

Our measure of the key variable, patenting activity, is computed as the stock of patent applications made by the firm. We compute this quantity for each firm and year as a perpetual inventory of past and present patent applications of the firm with a constant depreciation rate $(\delta)$ of 15 percent, as is common practice in the literature (see Griliches and Mairesse, 1984):

$$
\text { PATSTOCK }_{i, t}=(1-\delta) \text { PATSTOCK }_{i, t-1}+\text { PATAPPS }_{i, t}
$$

We also control for the size of the firms' tangible assets, measured as the log of those assets. Larger firms may be able to realize economies of scale and scope when doing $R \& D$ activities, which may affect their R\&D intensity either positively or negatively. This result was originally pointed out by Fisher and Temin (1973), who show that a finding that R\&D intensity increases with firm size is neither necessary nor sufficient to show that the productivity of R\&D increases with firm size or the size of the R\&D program. Therefore we have no prior expectation about the sign of this coefficient.

Because R\&D investment may also depend on the life cycle of the firm, and younger firms are often observed to invest relatively more in R\&D than older firms, we control for age-related effects by including the log of age, $\ln (A G E)$. Additionally, the dummy variable GROUP is included to take into account that firms that are part of an

\footnotetext{
${ }^{9}$ We also experimented with a debt measure based on a firm's total liabilities (current plus non-current liabilities), but the results were quite similar so we do not display them in the paper.
} 
enterprise group may conduct more $R \& D$ since firms associated with a group can benefit from intra-firm knowledge spillovers as well as from R\&D funding through intra-group sources. A set of yearly time dummies is included to account for overall business cycle effects and 16 sector dummies on the basis of the European standard industry classification (NACE Bel rev2) are included to capture differences in technological opportunities that determine R\&D investment. To avoid simultaneity bias due to feedback effects from the dependent variable to current explanatory variables, we use lagged values of all time-varying independent variables (with the exception of $A G E)$.

\subsection{Descriptive statistics}

Table 1 presents the descriptive statistics for these variables for the full sample as well as for the groups of small and larger firms separately. We define small firms as those whose employment averages less than 50 during the sample period, which is essentially the definition used by the European Commission. Out of a total of 4,390 firm-year observations $44 \%$ refer to small firms.

Average $R \& D$ to tangible assets ratio in the full sample is 0.88 corresponding to annual R\&D spending of about 3 million euros on average. Median spending is much lower, however, at about 132 thousand euros (not reported). Almost 20\% of firms have at least one patent in the sample period. The average patent stock is 1.09 and firms file on average 0.6 patents per year. In the group of patent-active firms, i.e. firms with at least one patent application the average number is 2.9 patents per year (not reported). The firms' long term debt is around 22 million euros on average resulting in a mean debt to tangible assets ratio of 1.34; the median is much lower at a ratio of 0.52 . The working capital to tangible assets ratio is 4.87 and firms employment averages 256 (median 64). The mean firm age is close to 29 years and $57 \%$ of the firms are part of an enterprise group.

When splitting our sample into small and larger firms, we see interesting differences in the main variables between these two groups. Small firms have significantly (at 1\% level) higher R\&D expenditures to tangible assets ratios, smaller patent stock and fewer patent applications in a given year. Small firms’ patents receive significantly fewer citations, reflected in smaller citations stocks. Moreover, these firms are younger, more often independent ventures and have lower debt ratios (DEBT/K), on 
average. The amount of working capital is also significantly lower for the sub-sample of small firms as one would expect, but the mean of the working capital to tangible assets ratio is larger for the group of small firms.

In terms of their basic characteristics, we believe that the firms in the sample are representative of Flemish R\&D performers. We base this assertion on two facts: 1) the sampling methodology is that used by government statistical agents to collect data for various R\&D reports, both Eurostat and OECD. 2) Key statistics of the sample, such as the patentee share of 20 per cent, are well in line with numbers for Europe in general. On average, 19\% of European manufacturing firms with innovation activity filed at least one patent. The share varies between 15\% in countries like Italy and Denmark, 18\% in the Netherlands, 24\% in Germany and 27\% in France (European Communities/Eurostat 2004, p. 60). Further, the firm-size distribution is similar to the one of other European countries like Germany, Austria, France and the UK where the large majority of firms employs less than 250 employees and the median firm size ranges between 40 and 50 employees (Rubini et al. 2012). 
Table 1: Descriptive Statistics (main variables)

\begin{tabular}{|c|c|c|c|c|c|}
\hline Variable & Units & Mean & Std. Dev. & Min & Max \\
\hline \multicolumn{6}{|c|}{ Full sample $(4,390$ obs. on 1,147 firms $)$} \\
\hline$R \& D_{i, t} / K_{i, t}$ & ratio & 0.88 & 3.88 & 0 & 128.57 \\
\hline PATSTOCK $_{\mathrm{t}-1}$ & count & 1.09 & 8.06 & 0 & 231.2 \\
\hline PATAPPS $_{t-1}$ & count & 0.60 & 4.52 & 0 & 132 \\
\hline CITSTOCK $_{t-1}$ & count & 9.72 & 181.72 & 0 & $5,667.5$ \\
\hline$W C A P_{i, t-1} / K_{i, t-1}$ & ratio & 4.87 & 9.40 & -0.91 & 112.26 \\
\hline$D E B T_{i, t-2} / K_{i, t-1}$ & ratio & 1.34 & 3.27 & 0 & 38.76 \\
\hline$K_{i, t-1}$ & million $€$ & 17.96 & 99.26 & 0.001 & $2,253.24$ \\
\hline$E M P_{i, t}$ & headcount & 255.70 & 693.01 & 1 & 11,575 \\
\hline$A G E_{i, t}$ & years & 28.79 & 19.82 & 5 & 138 \\
\hline GROUP $_{i}$ & dummy & 0.57 & 0.50 & 0 & 1 \\
\hline \multicolumn{6}{|c|}{ Large firms (2,428 obs. on 567 firms) } \\
\hline$R \& D_{i, t} / K_{i, t}$ & ratio & 0.50 & 1.81 & 0 & 27.81 \\
\hline PATSTOCK $_{t-1}$ & count & 1.89 & 10.77 & 0 & 231.2 \\
\hline PATAPPS $_{t-1}$ & count & 1.04 & 6.04 & 0 & 132 \\
\hline CITSTOCK $_{t-1}$ & count & 1.34 & 3.27 & 0 & 38.76 \\
\hline$W C A P_{i, t-1} / K_{i, t-1}$ & ratio & 17.49 & 244.09 & -0.82 & $5,667.5$ \\
\hline$D E B T_{i, t-2} / K_{i, t-1}$ & ratio & 1.59 & 3.79 & 0 & 38.76 \\
\hline$K_{i, t-1}$ & million $€$ & 31.72 & 131.86 & 0.02 & $2,253.24$ \\
\hline$E M P_{i, t}$ & headcount & 443.93 & 888.29 & 13 & 11,58 \\
\hline$A G E_{i, t}$ & years & 33.00 & 22.19 & 5 & 138 \\
\hline$G_{R O U P}$ & dummy & 0.76 & 0.43 & 0 & 1 \\
\hline \multicolumn{6}{|c|}{ Small firms (1,962 obs. on 580 firms) } \\
\hline$R \& D_{i, t} / K_{i, t}$ & ratio & 1.36 & 5.41 & 0 & 128.57 \\
\hline PATSTOCK $_{t-1}$ & count & 0.11 & 0.51 & 0 & 7.4 \\
\hline PATAPPS $_{t-1}$ & count & 0.06 & 0.34 & 0 & 5 \\
\hline CITSTOCK $_{t-1}$ & count & 0.10 & 1.29 & 0 & 36 \\
\hline$W C A P_{i, t-1} / K_{i, t-1}$ & ratio & 5.60 & 10.59 & -0.91 & 111.5 \\
\hline$D E B T_{i, t-2} / K_{i, t-1}$ & ratio & 1.04 & 2.44 & 0 & 38.13 \\
\hline$K_{i, t-1}$ & million $€$ & 0.94 & 2.27 & 1 & 49.63 \\
\hline$E M P_{i, t}$ & headcount & 22.77 & 14.00 & 1 & 85 \\
\hline$A G E_{i, t}$ & years & 23.58 & 14.85 & 6 & 106 \\
\hline$G_{R O U P}$ & dummy & 0.33 & 0.47 & 0 & 1 \\
\hline
\end{tabular}

\section{Econometric Analysis}

In the following econometric analysis, we estimate censored panel regression models as not all of our firms in the sample perform R\&D in each year, which results in a left censoring of the dependent variable. Small firms especially may conduct $R \& D$ only on an irregular basis. Indeed, in our sample the number of censored observations is 
larger in the group of firms with fewer than 50 employees. Thus, we estimate random effects Tobit models that can be written as

$$
\begin{aligned}
& y_{i t}=\max \left(0, x_{i t} \beta+c_{i}+u_{i t}\right), \quad i=1,2, \ldots, N, \quad t=1,2, \ldots, T \\
& u_{i t} \mid x_{i}, c_{i} \sim N\left(0, \sigma_{u}^{2}\right)
\end{aligned}
$$

where $y$ denotes the dependent variable, $x$ the set of regressors, $c$ a firm-specific timeconstant effect, and $u$ the usual random error term. The parameters to be estimated are denoted by the vector $\beta$.

The first specification of the model to be estimated assumes that there is no correlation between $c$ and $x$ (see Wooldridge, 2002, pp. 540-541, for further technical details). Note that it is not appropriate to estimate a fixed effects Tobit model, as the maximum likelihood estimator of this model is not consistent (see e.g. Cameron and Trivedi 2005). As the uncorrelatedness assumption between $x$ and $c$ can easily be challenged, we relax this assumption by adding "within” means of each of the time varying covariates to the set of regressors to proxy "quasi-fixed effects", following Wooldridge (2002). Thus, if $c_{i}=\psi+\bar{x}_{i} \xi+a_{i}$ we can write

$$
y_{i t}=\max \left(0, \psi+x_{i t} \beta+\bar{x}_{i} \xi+a_{i}+u_{i t}\right)
$$

with $u_{i t} \mid x_{i}, a_{i} \sim N\left(0, \sigma_{u}^{2}\right)$ and $a_{i} \sim N\left(0, \sigma_{a}^{2}\right)$.

The appropriateness of the Wooldridge model, i.e. that the assumption of uncorrelatedness between the firm-specific effect and the regressors is not valid, will be tested by the joint significance of the $x$-variables' “within” means.

The basic model for R\&D investment is specified as: ${ }^{10}$

$$
\begin{aligned}
\frac{R \& D_{i t}^{*}}{K_{i t}} & =\beta_{0}+\beta_{1} \ln \left(\text { PATSTOCK }_{i, t-1}\right)+\beta_{2} \frac{W C A P_{i, t-1}}{K_{i, t-1}}+\beta_{3} \frac{W C A P_{i, t-1}}{K_{i, t-1}} \times \ln \left(\text { PATSTOCK }_{i, t-1}\right) \\
& +\beta_{4} \frac{D E B T_{i, t-2}}{K_{i, t-1}}+\sum_{h=5}^{8} \beta_{h} Z_{i k}+\gamma_{i}+\delta_{t}+c_{i}+u_{i t}
\end{aligned}
$$

\footnotetext{
${ }^{10}$ Although the model contains a time-invariant firm-specific effect we also include the time-invariant regressors GROUP and the industry dummies, as the firm-specific effect is treated as a random component in the estimation.
} 
Where $Z_{i k}$ corresponds to the set of firm-level control variables including SIZE in terms of tangible assets, AGE and GROUP. $\gamma_{i}$ and $\delta_{t}$ denote the 16 two-digit industry and the 10 year dummies respectively. The model for the observable $R \& D / K$ ratio is the following:

$$
\frac{R \& D_{i t}}{K_{i t}}=\left\{\begin{array}{cl}
\frac{R \& D_{i t}^{*}}{K_{i t}} & \text { if } x_{i t} \beta+c_{i}+u_{i t}>0 \\
0 & \text { otherwise. }
\end{array}\right.
$$

We include an interaction term of the working capital ratio and the patent indicator to measure the impact of patenting activity on the firms' sensitivity in R\&D investment to the availability of internal liquidity as captured by working capital. The patent indicator PATSTOCK $\mathrm{i}_{i,-1}$ measures the firms discounted patent stock as described above at period $t-1$. We use the natural log of one plus PATSTOCK $K_{i, t-1}$ in estimation to because of the skewness of the patent distribution (and to avoid missing values when the stock is zero). One may also include an indicator that captures recent patenting activity, i.e. a dummy for new patent applications (PATDUMMY) that takes the value one if the firms filed for at least one patent in $t-1$.

One problem that arises when estimating $R \& D$ investment equations is the potential simultaneity between $R \& D$ and the variables such as leverage, size, etc used to predict it. We have tried to mitigate this problem by using lags of all our predictor variables, but given the intertemporal nature of firm strategies, especially those associated with R\&D behavior, this is not a complete solution. It might have been desirable to estimate dynamic panel data models since theoretical investment models are typically based on the firm's inter-temporal optimization problem conditional on the current level of (R\&D) capital stock (see Brown and Peterson 2011; Brown et al. 2012; Mulkay et al. (2001)). However, application of the methods used by these authors would require four consecutive observations per firm in order to conduct meaningful panel regressions. Our panel dataset is not only unbalanced but has also gaps in the time-series structure because firms did not necessarily respond to the surveys in adjacent years. Therefore, we found it impossible to estimate dynamic models given the sparseness of the data.

In addition, due to the unbalanced nature of our panel data, we could not follow the familiar panel data approach of using lagged values of the regressors as instrumental 
variables, as we would lose a large share of the observations. In addition, the validity of such instruments would be questionable as many variables show high persistency over time. Thus instruments external to the current model would be required. Unfortunately it is very difficult to think about appropriate instrumental variables in the present context even conceptually, and the availability of appropriate data constitutes another hurdle for implementing appropriate IV regressions.

\subsection{Estimation Results}

The results of the random effects panel model are presented on the left hand-side of Table 2 and the results for the model that allows for correlated effects by including the within sample means of the time variant firm characteristics are presented on the right panel. Table 2 shows the results of the specification with the PATSTOCK variable as outlined above. The first and fourth columns present the results for the full sample, columns two and five show the results for small firms and columns three and six for larger firms.

First, it should be noted that the tests of whether $x$ and $c$ are uncorrelated are rejected for the regressions for both subsamples (tests on joint significance on within means). Thus, we prefer the Wooldridge generalization of the random effects model over the 'traditional' random effects model. In the following, we therefore limit our discussion to these results.

As can be seen in Table 2, we observe a significant positive coefficient on lagged working capital intensity for the full sample. The sample split models, however, indicate that this effect is mainly driven by small firms. In line with previous literature identifying financing constraints by investments' sensitivity to internal liquidity, we may interpret the different size in the coefficients between small and large firms as an indication that smaller firms are more dependent on internal means for financing their R\&D (supporting Hypothesis 1).

The patent stock itself is related positively and significantly to $R \& D$ spending in all model specifications. Our main attention is directed at the interaction effect between the firms' past patent activity and the firm's liquidity. As can be gathered from Table 2 , the sign of the coefficient of the interaction term $\left(\text { WCAP }_{t-1} / K_{t-1}\right)^{*} \ln \left(\right.$ PATSTOCK $\left._{t-1}\right)$ is negative and significant, but only in the sample of small firms. Its negative sign suggests that the firm's patent stock helps to reduce the dependence on working 
capital (supporting Hypothesis 2 and 3). This "mitigation” effect is robust to the inclusion of controls for correlated fixed effects. In terms of the magnitude of the mitigation effect, we see that the interaction coefficient of -0.105 when compared to the working capital coefficient of 0.175 corresponds to about two-thirds of the initial effect. In other words, the larger a small firm’s patent stock, the lower its dependency on internal liquidity when investing in $\mathrm{R} \& \mathrm{D}$. In terms of marginal effects, we also find that the patent stock has a significant economic impact on investment. Consider a small firm that does not hold any patents and has otherwise average firm characteristics including an average value of $W C A P / K$. Now suppose it is hit by a shock in liquidity such that its value of $W C A P / K$ is reduced by one standard deviation. Consequently, its $R \& D$ investment to tangible assets ratio is expected to decline by about $48 \%$, other things equal. If, however, the same liquidity shock hits a small firm that patents at the average value of the patent stock distribution in the sample, its investment to assets ratio would only reduce by $23 \%$. Thus, the significant coefficient estimates of the liquidity, the patent stock and their interaction, also translate into economically significant results.

These insights are robust to the altering the specification by using a dummy variable for recent patenting activity only. ${ }^{11}$ Thus, in general, small firms depend highly on their internal resources, but having patent applications alleviate the constraint, on average. Thus, whatever attributes of the firms' patents are assumed to correlate with, the signal seems to be positive. In line with previous studies, we find that liquidity is less associated with R\&D in larger firms. In addition, although the past patent stock is strongly associated with current R\&D intensity, patents have no impact on the small liquidity coefficient, suggesting that there is no signaling role of patents for large firms.

We further tested for which thresholds in the firm size distribution these results hold. For that purpose, we interacted size with the three variables working capital, patent stock, and their interaction. The result are shown in Figure 1. Using a loglinear interaction, all the three coefficients become insignificant at about 100 employees and

\footnotetext{
${ }^{11}$ Detailed results are available from the authors upon request. The $\chi^{2}(3)$ for coefficient equality across small and large firms is 82.6 for patent applications and 75.1 for the patenting dummy.
} 
approach zero as firm size reaches 1000 employees. We also tried a splitting the sample at 100 employees instead of 50, and found that the results were similar but slightly weaker. ${ }^{12}$

To test whether the effects differ between sectors, we ran the models on different industry sub-groups. When we distinguish Information and Communication Technology (ICT) (518 obs.) from non-ICT sectors, we find positive and significant working capital coefficients and significant negative interaction effects in both groups. Interestingly, the working capital coefficient is much larger in the ICT group. When we distinguish manufacturing from services, we find that manufacturing drives the results, which is not surprising given the relative importance of patents in that sector. Dividing the sample further is really not feasible given the limited number of observations with positive patenting.

The control variables show the expected signs. Among the larger firms, more physical capital-intensive firms invest less in $\mathrm{R} \& \mathrm{D}$, while group membership is positively associated with R\&D for small firms. Not surprisingly, industry is a strong predictor of R\&D spending. Interestingly, for the sub-sample of small firms, we further find evidence for a sensitivity of R\&D to business cycle movements as captured by the year dummies, while larger firms’ R\&D spending seems less sensitive to fluctuations in the business cycle.

\footnotetext{
${ }^{12}$ For a sample split of young versus old firms, where young is defined as age less than or equal to 20 years (results are similar for a cut at 25 years), we find that both sub groups are sensitive to financing constraints and that this sensitivity is mitigated by patents. Similarly, testing young/small versus old/small we find again very similar patterns in both groups. These results point to the conclusion that not their age that constrains firms in our sample, but rather their size. It should be noted, however, that our sample contains firms that are at least active for five years, i.e are not truly nascent firms. The results in the paper also show that the variable age itself is never statistically significant in predicting R\&D intensity in the presence of the other variables.
} 
Figure 1: Coefficients as a function of average firm employment

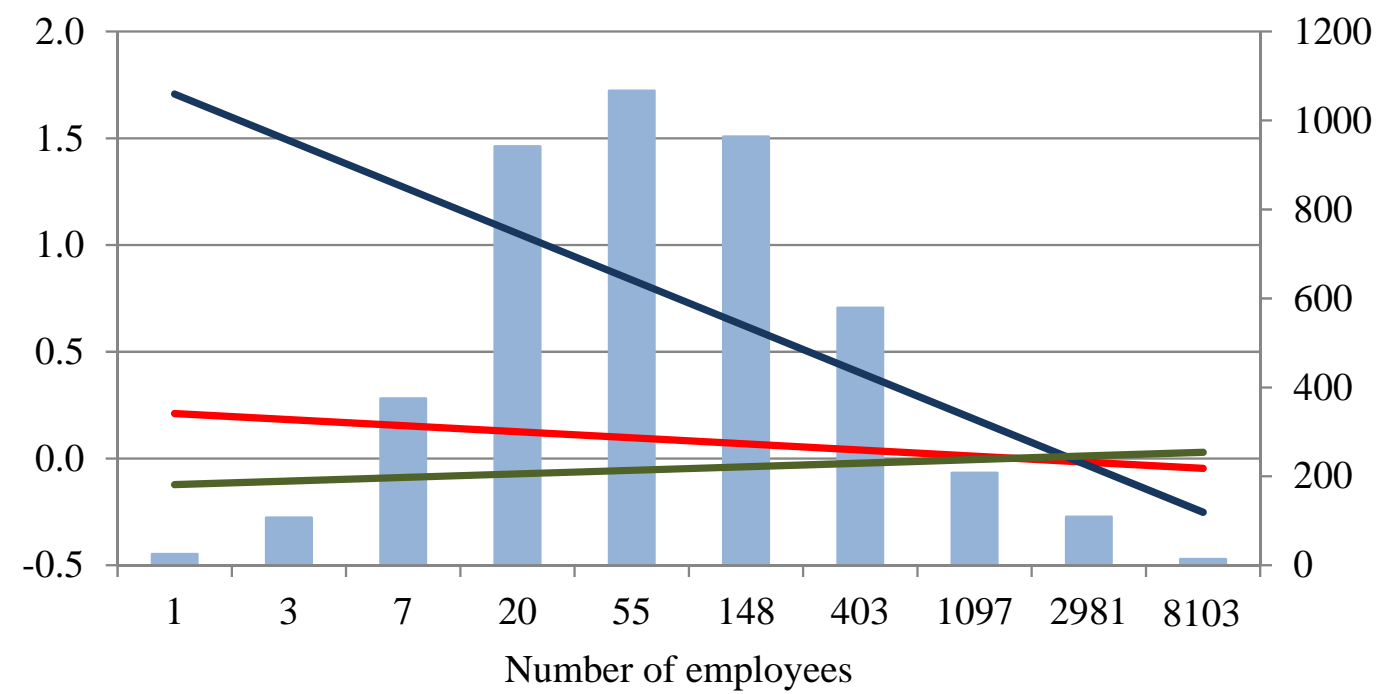

Number of firms

—Working capital coeff.

—Patent stock coeff.

-Interaction 
Table 2: Estimation results from Tobit regressions of R\&D intensity (R\&D over tangible assets) on lagged patent stock

\begin{tabular}{|c|c|c|c|c|c|c|}
\hline \multirow[b]{2}{*}{ Variable } & \multicolumn{3}{|c|}{ Random-Effects Panel Model } & \multicolumn{3}{|c|}{ Wooldridge Estimator } \\
\hline & full sample & $E M P L<50$ & EMPL > 50 & full sample & $E M P L<50$ & $E M P L>50$ \\
\hline \multirow[t]{2}{*}{$\ln (\text { PATSTOCK })_{t-1}$} & $0.785 * * *$ & $1.689 * * *$ & $0.409 * * *$ & $0.574 * *$ & $1.353^{*}$ & $0.243 * * *$ \\
\hline & $(0.156)$ & $(0.610)$ & $(0.071)$ & $(0.203)$ & $(0.740)$ & $(0.086)$ \\
\hline \multirow[t]{2}{*}{$W C A P_{t-1} / K_{t-1}$} & $0.111 * * *$ & $0.159 * * *$ & 0.008 & $0.115 * * *$ & $0.175 * * *$ & -0.001 \\
\hline & $(0.009)$ & $(0.016)$ & $(0.006)$ & $(0.010)$ & $(0.019)$ & $(0.007)$ \\
\hline \multirow{2}{*}{$\left(\right.$ WCAP $\left._{t-1} / K_{t-1}\right) * \ln (\text { PATSTOCK })_{t-1}$} & $-0.051 * * *$ & $-0.105 * * *$ & 0.001 & $-0.052 * * *$ & $-0.105 * * *$ & 0.003 \\
\hline & $(0.010)$ & $(0.023)$ & $(0.005)$ & $(0.010)$ & $(0.023)$ & $(0.005)$ \\
\hline \multirow[t]{2}{*}{$D E B T_{t-2} / K_{t-1}$} & $0.042 * *$ & $0.104 *$ & $0.045 * * *$ & $0.043^{*}$ & 0.085 & $0.045 * * *$ \\
\hline & $(0.021)$ & $(0.054)$ & $(0.010)$ & $(0.023)$ & $(0.062)$ & $(0.011)$ \\
\hline \multirow[t]{2}{*}{$\ln \left(K_{t-1}\right)$} & $-0.368 * * *$ & $-0.581 * * *$ & $-0.265 * * *$ & -0.216 & 0.013 & $-0.422 * * *$ \\
\hline & $(0.062)$ & $(0.152)$ & $(0.044)$ & $(0.125)$ & $(0.248)$ & $(0.071)$ \\
\hline \multirow[t]{2}{*}{$\ln \left(A G E_{t}\right)$} & -0.120 & -0.365 & 0.029 & -0.096 & -0.289 & 0.007 \\
\hline & $(0.181)$ & $(0.371)$ & $(0.111)$ & $(0.182)$ & $(0.373)$ & $(0.111)$ \\
\hline \multirow[t]{2}{*}{$G R O U P_{t}$} & $0.295 *$ & $0.695 * *$ & 0.006 & $0.312 *$ & $0.661 * *$ & -0.016 \\
\hline & $(0.168)$ & $(0.334)$ & $(0.099)$ & $(0.170)$ & $(0.337)$ & $(0.099)$ \\
\hline Joint sign. of time dummies $\chi^{2}(9)$ & $23.0 * * *$ & $22.1 * * *$ & 13.2 & $23.9 * * *$ & $25.1 * * *$ & 14.2 \\
\hline Joint sign. of ind. dummies $\chi^{2}(15)$ & $102.2^{* * *}$ & $55.6 * * *$ & $68.0 * * *$ & $96.2 * * *$ & $49.7 * * *$ & $66.4 * * *$ \\
\hline Joint sign. of within means $\chi^{2}(4)$ & - & - & - & 5.8 & $11.3^{* *}$ & $18.0^{* * *}$ \\
\hline Log-Likelihood & $-10,118.7$ & $-5,093.6$ & $-3,717.3$ & $-10,115.8$ & $-5,088.0$ & $-3,708.4$ \\
\hline$\rho($ s.e. $)$ & $0.633(0.015)$ & $0.564(0.025)$ & $0.733(0.017)$ & $0.633(0.015)$ & $0.566(0.024)$ & $0.733(0.016)$ \\
\hline \# observations & 4,390 & 1,962 & 2,428 & 4,390 & 1,962 & 2,428 \\
\hline \# censored observations & 666 & 305 & 361 & 666 & 305 & 361 \\
\hline
\end{tabular}

Notes: Standard errors are in parentheses. ${ }^{* * *}\left(* *,{ }^{*}\right)$ indicate a significance level of $1 \%(5 \%, 10 \%)$. All models include an intercept (not shown). Coefficients of variables' within means in Wooldridge model are omitted from the table. The value of $\rho$ indicates the share of the total variance which is due to the cross-sectional variation. 


\subsection{Patent signal or patent value?}

The previous results suggest that patents affect the firms' dependence on internal funds for conducting $\mathrm{R} \& \mathrm{D}$ for small firms. If this effect were due to a signaling value of patents then we would expect the effect to be related to the patent application and not necessarily to the ex-post value of the patented technology. In other words, the effect should stem from the patent application independently of whether or not the technology turned out to be highly valuable in the end. For the purpose of testing this, we use the forward citations to the patent applied for in $t$ 1 by the firm. As shown in previous research, the value distribution of patented inventions is subject to considerable uncertainty early in the patent life and ultimately highly skewed. Using a number of measures (renewal rates, citations, surveys, etc.) researchers have found that only a few patents turn out to be of high economic value, while the remainder are worth almost nothing (Pakes, 1985; Schankerman and Pakes, 1986; Harhoff et al., 1999; Deng, 2007). Thus, one does not expect patents to alleviate financing constraints unless patents signal something more, for example overall technological competencies, than simply the expected rents from appropriating returns on $R \& D$ via IP protection. This would make the patent right itself valuable, independently of the value of the underlying technology. Hall et al. (2005) suggest using forward patent citations (references to the patent in subsequent patent applications) as a patent value indicator. The more citations a firm's patents receive, the more influential are these patents for follow-on technology developments, and consequently the higher is the assumed economic value of the patents. Research on the appropriateness of forward citations as value indicator found citations to correlate positively and significantly with patents' economic value reported in surveys (Harhoff et al., 1999; Jaffe et al., 2000; Gambardella et al. (2008).

In the sample of small firms, we observe only very few patenting firms that receive citations to their patents at all (18 firms, corresponding to slightly less than one third of the small firms who patent). In other words, the reported signaling effect is unlikely to be due to the ex-post value of the underlying invention, as proxied by the average number of forwards citations to the patent in a five year-window after the patent was filed.

Among larger firms, about 12 percent (or half of the patenting firms) receive citations to their

patents. On average, these firms received 8 citations to their patents in the sample period. This number is of course downward biased by the number of non-patenting firms in our sample. 
Among the firms with at least one patent, the overall number of citations is 27 with a maximum of 4554 total citations. More meaningful is the average number of citations per patent that firms receive, on average. In the sub-sample of large firms this number is 0.47 , with a maximum of 255 citations per patent. It should be noted that we consider patent profiles at the level of the firms which implies that we aggregate citations over all the patents the firm applied for in a given year and then divide by patents

The citations per patent variable has a very skewed distribution, as expected. Table 3 below shows the distribution of the citation stock-patent stock ratio (lagged) for our sample:

Table 3: Citation Distribution

\begin{tabular}{l|c}
\hline CITSTOCK $_{\boldsymbol{t}-\mathbf{1}}$ PATSTOCK $_{\boldsymbol{t} \mathbf{- 1}}$ & Number of observations \\
\hline None & 4148 \\
$0-1$ & 75 \\
$1-2$ & 47 \\
$2-5$ & 48 \\
$5-10$ & 35 \\
More than 10 & 37 \\
\hline
\end{tabular}

Given the skewness of the citation distribution, we therefore experimented with a number of specifications of the citations variable: the lagged cite stock-patent stock ratio (in levels and logs), the previous year's citation/patent ratio (in levels and logs), and a simple dummy for the 242 observations with a nonzero citation stock. The citations stock (CITSTOCK) is calculated in the same fashion as the patent stock. The results are presented in Table 4, for the whole sample of firms. The coefficients of WCAP/K and the signs and significance levels of the control variables are comparable to the previous specification. Neither the citations term nor its interaction with working capital is ever significant, singly or jointly, supporting Hypothesis 4 . $^{13}$

The irrelevance of the ex-post patent quality points to the conclusion that the signalling value of a patent is irrespective of the actual value of the patented technology for small firms and

\footnotetext{
${ }^{13}$ We also experimented with using a series of dummies for different levels of average cites per patent, as in Hall et al. (2005), but without success.
} 
controlling for patent quality does not compromise the result for larger firms. ${ }^{14}$ We caution that this conclusion may be somewhat weaker than the conclusion that patents matter for financing, for two reasons: 1) citations may be a relatively weak indicator of value, especially citations based on EPO data, which are fewer in number; 2) these citations have been collected over a relatively short horizon.

\section{Conclusion}

Previous literature has suggested that patents may a serve as a signal to lenders and investors easing access to external financing in addition to their original function of protecting an invention from imitation. The current study was motivated by a gap in the literature on the role of patents as quality signals for established R\&D-active firms. The role of patents as quality signals for these firms, unlike for start-up firms and entrepreneurial ventures, has received little systematic treatment so far. The focus on a European economy allowed a study of the certification effects for bank loans, as they constitute the most important source of external funding for most SMEs in Europe.

In line with previous research, the results showed that small firms are more likely to rely on internal liquidity to fund their R\&D activities as a result of limited access to external financing. Moreover, the results showed that patenting activity may help small firms to attract external financing more easily compared to non-patenting firms. Hence, their R\&D spending relies to a lesser extent on available internal funds. We also found that the mitigating effect of patent applications is not due to the actual ex-post value of the patented technology, and we therefore conclude that patents do have some signaling effect beyond the fact that they proxy for the underlying technological and economic value of the patented invention. An alternative and related interpretation of our findings is that the private value of the invention is so uncertain at the time of application that capital markets and financial institutions are unable to distinguish

\footnotetext{
${ }^{14}$ Note that the number of citations is always truncated. Moreover, in our case, observations in the years later than 2008 have a shorter citation window than five years. We tested the sensitivity of our results to dropping these observations and found that the coefficients' magnitude and significance is hardly affected.
} 
among the various patents held by small firms, although they do evaluate the mere existence of a patent application positively.

Our findings add to previous research that suggested that patents play a particularly valuable signaling role in the start-up phase of a firm by finding patents to be important for small firms to attract external financing even if they are already established. The results thus stress that firms size may not only determine the likelihood that firms face financing constraints for $R \& D$, but also whether patent help firms to signal technology competencies. As about half of the firms in our sample qualify as being small, the significance of the findings for technological advances at the level of the Flemish economy is clear. If small firms slow down growth in order to adapt their growth to the rates that can be maintained with its available financial means, as a consequence, growth of such firms is constrained by internal finance postponing technological advances and forgoing some technological opportunities. For many small technology firms, the signaling value of patents may thus be valuable adding to the protection function of patents.

In light of the relatively high share of small and medium-sized firms in many European regions, these insights are interesting beyond the region of Flanders. Testing the generalizability of the results to other regions or countries, however, would require conducting a comparable study on internationally harmonized data. Such an approach is feasible, but requires researchers who have access to non-anonymized data on firm-level $R \& D$ and other firm characteristics, country by country. We would certainly expect to find similar results on other European countries whose economies and financial markets resemble Belgium's.

Long (2002) argues that investors give high importance to patent counts when looking at established firms. In contrast, when looking at less-established firms, investors investigate the quality as well as the quantity of the patents. This may have affected our findings as the present study explicitly studied established firms. So it might be, that if we had considered young firms in our sample, patent quality would have mattered more. This distinction should be addressed in more detail in future research. Moreover, as individual patents can convey information about an particular invention, "patent portfolios may provide information about the lines of research a firm is conducting and how quickly the research is proceeding” (Long 2001). Future research may therefore benefit from a more detailed assessment of the firms' patent portfolios in order to disentangle the portfolio effect from the signal value of the individual patent. 
Future research would also benefit from studying in much greater detail how the signal varies between different external investors and also whether it matters for attracting public R\&D funding. Previous research suggested that public funding agencies may act like private investors in the sense that they favor less uncertain projects that are more likely to result in marketable products sooner.

Finally, we cannot rule out that our findings are subject to some degree of simultaneity bias. Therefore it would be useful to find exogeneous shocks to financing in order to identify the parameters of the R\&D investment equation with fewer endogeneity concerns.

Despite these limitations, this study contributes to the literature on patent signals in several ways. First, studying a sample of firms in Europe, this study is the first to investigate signalling value of European patent application. Second, while previous evidence is mainly found for early stage financing such as Venture Capital in selected industries, in this paper we explicitly focused on more established firms for which the financing constraints argument cannot be explained by a liability of newness. Third, we find that the patent signalling effect does not seem to arise in larger firms and, fourth, that the effect on external financing tends to be driven by the mere presence of patents rather than observable ex post indicators of the value of those inventions. It would be highly desirable for future work to investigate the replicability of these results in other economies. 
Table 4: Estimation results from Tobit regressions with Wooldridge correction of R\&D over tangible assets with citations form of citation variable $\left(\right.$ CITATIONS $\left._{t-1}\right)$

\begin{tabular}{|c|c|c|c|c|c|}
\hline Variable & $\ln ($ CITSTOCK/PATSTOCK) & СITSTOCK/PATSTOCK & $\begin{array}{c}\ln \text { (average citations per } \\
\text { patent) }\end{array}$ & $\begin{array}{c}\text { average citations per } \\
\text { patent }\end{array}$ & $\begin{array}{c}\text { dummy (non-zero } \\
\text { CITSTOCK) }\end{array}$ \\
\hline \multirow[t]{2}{*}{ PATSTOCK $_{t-1}$} & $0.491 * *$ & $0.780^{* * *}$ & $0.598 * * *$ & $0.588 * * *$ & $0.616^{* * *}$ \\
\hline & $(0.209)$ & $(0.156)$ & $(0.199)$ & $(0.199)$ & $(0.203)$ \\
\hline \multirow[t]{2}{*}{$W C A P_{t-1} / K_{t-1}$} & $0.116^{* * *}$ & $0.111 * * *$ & $0.115 * * *$ & 0.115 & $0.115^{* * *}$ \\
\hline & $(0.010)$ & $(0.009)$ & $(0.010)$ & $(0.010)$ & $(0.010)$ \\
\hline \multirow[t]{2}{*}{$\left(W_{C A P}{ }_{t-1} / K_{t-1}\right) * P A T S T O C K_{t-1}$} & $-0.032 *$ & $-0.051 * * *$ & $-0.054 * * *$ & $-0.052 * * *$ & $-0.055 * * *$ \\
\hline & $(0.017)$ & $(0.010)$ & $(0.011)$ & $(0.011)$ & $(0.011)$ \\
\hline \multirow[t]{2}{*}{ CITATIONS $_{t-1}$} & -0.169 & 0.000 & -0.155 & -0.003 & -0.398 \\
\hline & $(0.125)$ & $(0.019)$ & $(0.192)$ & $(0.021)$ & $(0.389)$ \\
\hline \multirow{2}{*}{$\left(W_{C A P}{ }_{t-1} / K_{t-1}\right) * C I T A T I O N S_{t-1}$} & 0.029 & 0.002 & 0.031 & 0.003 & 0.063 \\
\hline & $(0.018)$ & $(0.007)$ & $(0.037)$ & $(0.010)$ & $(0.065)$ \\
\hline \multirow[t]{2}{*}{$D E B T_{t-2} / K_{t-1}$} & $0.044 *$ & $0.042 * *$ & $0.044 *$ & $0.044 *$ & $0.044 *$ \\
\hline & $(0.023)$ & $(0.021)$ & $(0.023)$ & $(0.023)$ & $(0.023)$ \\
\hline \multirow[t]{2}{*}{$\ln \left(K_{t-1}\right)$} & $-0.218 *$ & $-0.368 * * *$ & $-0.218^{*}$ & $-0.216^{*}$ & $-0.224^{*}$ \\
\hline & $(0.125)$ & $(0.062)$ & $(0.125)$ & $(0.125)$ & $(0.125)$ \\
\hline \multirow[t]{2}{*}{$\ln \left(A G E_{t-1}\right)$} & -0.093 & -0.118 & -0.097 & -0.095 & -0.092 \\
\hline & $(0.182)$ & $(0.181)$ & $(0.183)$ & $(0.183)$ & $(0.182)$ \\
\hline \multirow[t]{2}{*}{ GROUP } & $0.319 *$ & 0.296* & $0.315 *$ & $0.311^{*}$ & 0.319* \\
\hline & $(0.170)$ & $(0.168)$ & $(0.170)$ & $(0.170)$ & $(0.169)$ \\
\hline Joint test for citation variables $\chi^{2}(2)$ & 3.1 & 0.1 & 0.9 & 0.1 & 1.3 \\
\hline Joint sign. of time dummies $\chi^{2}(9)$ & $24.1^{* * *}$ & $23.9 * * *$ & $24.0 * * *$ & $23.9 * * *$ & $23.6 * * *$ \\
\hline Joint sign. of ind. dummies $\chi^{2}(15)$ & $95.7 * * *$ & $96.2 * * *$ & $96.1 * * *$ & $95.9 * * *$ & $96.4 * * *$ \\
\hline Joint sign. of within means $\chi^{2}(4)$ & 5.9 & 5.7 & 6.0 & 5.8 & $9.5 *$ \\
\hline Log-Likelihood & $-10,114.2$ & $-10,115.8$ & $-10,115.3$ & $-10,115.8$ & $-10,115.3$ \\
\hline$\rho($ s.e $)$ & $0.632(0.015)$ & $0.633(0.015)$ & $0.632(0.015)$ & $0.633(0.015)$ & $0.631(0.015)$ \\
\hline \# observations & 4,390 & 4,390 & 4,390 & 4,390 & 4,390 \\
\hline \# censored observations & 666 & 666 & 666 & 666 & 666 \\
\hline
\end{tabular}

Notes: Standard errors are in parentheses. *** (**,*) indicate a significance level of $1 \%(5 \%, 10 \%)$. All models include an intercept (not shown). Coefficients of variables’ within means in Wooldridge model are omitted from the table. The value of $\rho$ indicates the share of the total variance which is due to the cross-sectional variation. 


\section{References}

Anton, J. and Yao, D. (2002). The Sale of Ideas: Strategic Disclosure, Property Rights, and Contracting, Review of Economic Studies, 69(3), 513-531.

Arora, A., Fosfuri, A. and Gambardella, A. (2001). Markets for Technology: The Economics of Innovation and Corporate Strategy, MIT Press, Cambridge.

Baum, J.A. and Silverman, B.S. (2004). Picking Winners or Building Them? Alliance, Intellectual, and Human Capital as Selection Criteria in Venture Financing and Performance of Biotechnology Startups, Journal of Business Venturing 19(3), 411-436.

Berger, A. and Udell, G. (1998). The Economies of Small Business Finance: The Roles of Private Equity and Debt Markets in the Financial Growth Cycle, Journal of Banking and Finance 22(6-8), 613-673.

Bessen, J. and Maskin, E. (2009). Sequential Innovation, Patents, and Imitation, RAND Journal of Economics 40(4), 611-635.

Bhattacharya, S. and Ritter, J. (1983). Innovation and Communication: Signaling with Partial Disclosure, Review of Economic Studies 50(2), 331-346.

Bond, S. and Van Reenen, J. (2007). Microeconometric Models of Investment and Employment, in: J.J. Heckman and E.E. Leamer (eds.), Handbook of Econometrics 6, London, North-Holland, 4417-4498.

Bougheas, S., Görg, H. and Strobl, E. (2003). Is R\&D Financially Constrained? Theory and Evidence from Irish Manufacturing, Review of Industrial Organization 22(2), 159-174.

Brown, J.R. and Petersen, B.C. (2011), Cash holdings and R\&D smoothing, Journal of Corporate Finance 17, 694-709.

Brown, J.R., Martinsson, G. and Petersen, B.C. (2012). Do financing constraints matter for R\&D?, European Economic Review 56, 1512-1529.

Cameron, A.C. and Trivedi, P.K. (2005). Microeconometrics: Methods and Applications, New York, Cambridge University Press.

Carpenter, R. and Petersen, B.C. (2002). Capital Market Imperfections, High-Tech Investment, and New Equity Financing, Economic Journal 112, 54-72.

Christie, A., C. Dent,J. Liddicoat, and A. Lim (2013). What Difference Does Patent Examination Make?: An Analysis of the Effect of Examination in the USPTO, the EPO and APO. Paper presented at the TILEC Workshop on Innovation and the Patent System, June 20-21.

Cockburn, I. and Wagner, S. (2007). Patents and the Survival of Internet-Related IPOs, NBER Working Paper No. 13146.

Conti, A., Thursby, M.C., and Rothaermel, F.T. (2013). Show Me the Right Stuff: Signals for High Tech Startups, Journal of Economics \& Management Strategy, 20(2), 341-364.

Conti, A., Thursby, M.C., and Thursby, J. (2013). Patents as Signals for Startup Financing, The Journal of Industrial Economics, 61(3), 592-622. 
Czarnitzki, D., Hall, B.H. and Oriani, R. (2006). The Market Valuation of Knowledge Assets in US and European Firms, in: D. Bosworth and E. Webster (eds.): The Management of Intellectual Property, Cheltenham, Edward Elgar: 111-131.

Czarnitzki, D. and Hottenrott, H. (2010). Financing Constraints for Industrial Innovation: What do we know?, Review of Business and Economics 55(3), 346362.

Czarnitzki, D. and Hottenrott, H. (2011a). R\&D Investment and Financing Constraints of Small and Medium-Sized Firms, Small Business Economics 36(1), 65-83.

Czarnitzki, D. and Hottenrott, H. (2011b). Financial Constraints: Routine versus Cutting Edge R\&D Investment, Journal of Economics and Management Strategy 20(1), 121-157.

Deeds, D., DeCarolis, D. and Coombs, J. (1997). The Impact of Firm Specific Capabilities on the Amount of Capital Raise in an Initial Public Offering: Evidence From the Biotechnology Industry, Journal of Business Venturing 12, 165-187.

Deloof, M. (1998). Internal Capital Markets, Bank Borrowing, and Financing Constraints: Evidence From Belgian Firms, Journal of Business Finance and Accounting, 25(7\&8), 945-968.

Deloof, M. and Jegers, M. (1999). Trade Credit, Corporate Groups, and the Financing of Belgian Firms, Journal of Business Finance and Accounting 26(7\&8), 945-966.

Deng, Y. (2007). Private Value of European Patents, European Economic Review 51, $1785-1812$.

European Communities / Eurostat (2004), Innovation in Europe Results for the EU, Iceland and Norway, in: Panorama of the European Union, European Commission, Theme 9 Science and Technology, Brussels.

Fazzari, S., Hubbard, R. and Petersen, B.C. (1988). Financing Constraints and Corporate Investment, Brookings Papers on Economic Activity 1, 141-206.

Fazzari, S.M. and Petersen, B.C. (1993). Working Capital and Fixed Investments: New Evidence on Financing Constraints, RAND Journal of Economics, 24(3), 328-342.

Fisher, F.M. and P. Temin (1973). Returns to Scale in Research and Development: What Does the Schumpeterian Hypothesis Imply? Journal of Political Economy 81(1), 56-70.

Fort, T. C., Haltiwanger, J., Jarmin, R. S., and Miranda, J. (2013). How Firms Respond to Business Cycles: The Role of Firm Age and Firm Size, IMF Economic Review 61(3), 520-559.

Gambardella, A., Harhoff, D. and Verspagen, B. (2008). The Value of European Patents, European Management Review 5, 69-84.

Griliches, Z. and Mairesse, J. (1984). Productivity and R\&D at the Firm Level, in: Z. Griliches (ed.), R\&D, Patents, and Productivity. Chicago, University of Chicago Press.

Griliches, Z. (1986). Productivity, R and D, and Basic Research at the Firm Level in the 1970's, American Economic Review, 76(1), 141-154. 
Griliches, Z., Pakes, A. and Hall, B.H. (1987). The Value of Patents as Indicators of Inventive Activity, in: Economic Policy and Technological Performance, P. Dasgupta and P. Stoneman (eds.), Cambridge University Press, 97-124.

Haeussler, C., Harhoff, D. and Mueller, E. (2009). To Be Financed or Not - The Role of Patents for Venture Capital Financing, ZEW Discussion Paper No. 09-003.

Hall, B.H. (1992). Research and Development at the Firm Level: Does the Source of Financing Matter? Cambridge, Mass.: NBER Working Paper No. 4096.

Hall, B.H. (2000). Innovation and Market Value, in: R. Barrell, G. Mason and M. O’Mahoney (eds.), Productivity, Innovation and Economic Performance, Cambridge: Cambridge University Press.

Hall, B.H., C. Helmers, M. Rogers and V. Sena (2013). The importance (or not) of patents to UK firms. Oxford Economic Papers 65(3), 603-629.

Hall, B.H., A.B. Jaffe and M. Trajtenberg (2005). Market Value and Patent Citations. RAND Journal of Economics 36, 16-38.

Hall, B.H. and Kruiniker, H. (1995). The Role of Working Capital in the Investment Process, unpublished manuscript, Berkeley.

Hall, B. H. and Lerner, J. (2010), The Financing of R\&D and Innovation, in: Hall, B. and N. Rosenberg (Eds.), Handbook of the Economics of Innovation, ElsevierNorth Holland, Version August 2009.

Hall, B. H. and Ziedonis, R. H. (2001), The Patent Paradox Revisited: an Empirical Study of Patenting in the U.S. Semiconductor Industry, 1979-1995, RAND Journal of Economics, 32(1), 101-128.

Hall, B. H., G. Thoma and S. Torrisi (2007). The Market Value of Patents and R\&D: Evidence from European Firms. Cambridge, MA: NBER Working Paper No. 13428.

Hao, K.Y. and Jaffe, A.B. (1993). Effect Of Liquidity On Firms' R\&D Spending, Economics of Innovation and New Technology, 2(4), 275 - 282.

Harhoff, D. (1998). Are There Financing Constraints for R\&D and Investment in German Manufacturing Firms? Annales d' Economie et de Statistique 49/50, 421456.

Harhoff, D., Narin, F., Scherer, F.M. and Vopel, K. (1999). Citation Frequency and the Value of Patented Innovation, Review of Economics and Statistics 81(3), 511-515.

Harhoff, D. (2009). The Role of Patents and Licenses in Securing External Finance for Innovation, European Investment Bank (EIB) Papers 14(2), 75-97.

Heeley, M.B., Matusik, S.F., Jain, N. (2007). Innovation, Appropriability, and the Underpricing of Initial Public Offerings, Academy of Management Journal 50(1), 209-225.

Helmers, C. and Rogers, M. (2011). Does Patenting Help High-Tech Start-ups?, Research Policy, 40(7), 1016-1027.

Henderson, R. and Cockburn, I. (1994). Measuring Competence? Exploring Firm Effects in Pharmaceutical Research, Strategic Management Journal 15(S1), 6384. 
Himmelberg, C. and Peterson, B. (1994). R\&D and Internal Finance: A Panel Study of Small Firms in High-Tech Industries, Review of Economics and Statistics 76, 3851.

Hoenen, S., Kolympiris, C., Schoenmakers, W. and Kalaitzandonakes, N. (2014), The diminishing signaling value of patents between early rounds of venture capital financing, Research Policy, forthcoming. http://dx.doi.org/10.1016/ j.respol.2014.01.006.

Hottenrott, H. and Peters, B. (2012). Innovative Capability and Financing Constraints for Innovation: More Money, More Innovation?, Review of Economics and Statistics 94(4), 1126-1142.

Hsu, D. and Ziedonis, R. (2013). Resources as Dual Sources of Advantage: Implications for Valuing Entrepreneurial-Firm Patents, Strategic Management Journal 34, 761-781.

Hubbard, R. (1998). Capital-Market Imperfections and Investment, Journal of Economic Literature 36, 193-225.

Jaffe, A. and Lerner, J. (2004). Innovation and Its Discontents: How Our Broken Patent System is Endangering Innovation and Progress and What to Do About it, Princeton, N.J. Princeton University Press.

Jaffe, A.B., Trajtenberg M. and Fogarty, M. (2000). Knowledge Spillovers and Patent Citations: Evidence from a Survey of Inventors, American Economic Review 90(2), 215-218.

Jensen, M. (1986). Agency Cost of Free Cash Flow, Corporate Finance, and Takeovers, American Economic Review 76, 323-339.

Jensen, M. and Meckling, W. (1976). The Theory of the Firm: Managerial Behavior, Agency Cost, and Ownership Structure, Journal of Financial Economics 3, 305360.

Kaplan, S. and Zingales, L. (1997). Do Investment-Cash Flow Sensitivities Provide Useful Measures of Financing Constraints?, Quarterly Journal of Economics 112(1), 169-215.

Kaplan, S. and Zingales, L. (2000). Investment-Cash Flow Sensitivities are not Valid Measures of Financing Constraints, Quarterly Journal of Economics 115(2), 707712.

Kulatilaka, N. and Lihui, L. (2006), Impact of Licensing on Investment and Financing of Technology Development, Management Science 52(12), 1824-1837.

Lahr, H. and Mina, A. (2013), Dynamic financial constraints and innovation: Evidence from the UK Innovation Surveys, European Conference on Corporate R\&D and Innovation CONCORDi-2013 conference paper, Seville (Spain).

Lanjouw, J.O. and M. Schankerman (2004). Protecting Intellectual Property Rights: Are Small Firms Handicapped? Journal of Law and Economics 47, 45-74.

Leland, H. and Pyle, D. (1977). Informational Asymmetries, Financial Structure, and Financial Intermediation, Journal of Finance 32, 371-387

Lemley, M.A. (2000). Reconceiving Patents in the Age of Venture Capital, Journal of Small and Emerging Business Law 4, 137-148. 
Levitas, E. and McFadyen, M.A. (2009), Managing Liquidity in Research-Intensive Firms: Signaling and Cash Flow Effects of Patents and Alliance Activities, Strategic Management Journal 30(6), 659-678.

Long, C. (2002). Patent Signals, University of Chicago Law Review 69(2), 625-679.

MacMillan, I.C., Siegel, R. and Subbanarasimha, P.N. (1985). Criteria Used by Venture Capitalists to Evaluate New Venture Proposals, Journal of Business Venturing $1(1), 119-128$.

Mann, R.J. and Sager, T.W. (2007), Patents, Venture Capital, and Software Start-ups, Research Policy 36(2), 193-208.

Mansfield, E. (1986). Patents and Innovation: An Empirical Study, Management Science, 32(2), 173-181.

Mina, A., Lahr, H. and Hughes, A. (2013), The Demand and Supply of External Finance for Innovative Firms, Industrial and Corporate Change 22(4), 869-901.

Mulkay, B., B.H. Hall and J. Mairesse (2001). Investment and R\&D in France and in the United States. In Herrman, Heinz, and Rolf Strauch (eds.), Investing Today for the World of Tomorrow, Springer Verlag. Also available as a National Bureau of Economic Research Working Paper w8038. Cambridge, MA.

Myers, S. and Majluf, N. (1984). Corporate Financing and Investment Decisions When Firms Have Information That Investors do Not, Journal of Financial Economics $13,187-221$.

OECD (1993, 2002). Frascati Manual: Proposed Standard Practice for Surveys on Research and Experimental Development, Luxembourg.

Pakes, A. (1985). On Patents, R\&D, and the Stock Market Rate of Return, Journal of Political Economy 93(21), 390-408.

Rubini, L., Desmet, K., Piguillem, F. and Crespo, A. (2012), Breaking Down the Barriers to Firm Growth in Europe: the Fourth EFIGE Policy Report, Bruegel Blueprint Series, Volume XVIII, Brussels.

Schankerman, M. and Pakes, A. (1996). Estimates of the Value of Patent Rights in European Countries during the Post-1950 Period, The Economic Journal 96, 1052-1076.

Schneider C. and Veugelers R. (2010). On Young Innovative Companies: Why They Matter and How (not) to Policy Support Them, Industrial and Corporate Change 19(4), 969 - 1007.

Spence, M. (1973). Job Market Signaling, Quarterly Journal of Economics 87(3), 355374.

Stuart, T.E., Hoang, H. and Hybels, R. (1999), Interorganizational Endorsements and the Performance of Entrepreneurial Ventures, Administrative Science Quarterly 44(2), 315-349.

Van Pottelsberghe de la Potterie, B. (2011). The Quality Factor in Patent Systems, Industrial and Corporate Change, 20(6), 1755-1793.

Webb C., Dernis, H., Harhoff D. and Hoisl, K. (2005). Analyzing European and International Patent Citations: A Set of EPO Database Building Blocks. STI Working Paper 2005/9, OECD. 
Wooldridge, J.M. (2002). Econometric Analysis of Cross Section and Panel Data, MIT Press, Cambridge, Massachusetts. 


\section{Appendix}

Table A1: Industry classifications

\begin{tabular}{cllccc}
\hline Industry & NACE rev. 2 & Description & Firms & Observations & \% \\
\hline 1 & $10,11,12$ & Food and Tobacco & 107 & 394 & 8.97 \\
2 & $13,14,15$ & Textiles, Clothing and Leather & 79 & 302 & 6.88 \\
3 & 16,31 & Wood and Furniture & 42 & 137 & 3.12 \\
4 & 17,18 & Paper & 19 & 99 & 2.26 \\
5 & 19,20 & Chemicals & 85 & 357 & 8.13 \\
6 & 21 & Pharmaceuticals & 19 & 81 & 1.85 \\
7 & 22 & Rubber and Plastic & 60 & 225 & 5.13 \\
8 & $24,25,33$ & Metal & 94 & 389 & 8.86 \\
9 & 27,28 & Machines and Equipment & 148 & 606 & 13.80 \\
10 & 26 & ICT & 58 & 245 & 5.58 \\
11 & 29,30 & Transport & 30 & 123 & 2.80 \\
12 & 41 & Building and Construction & 33 & 110 & 2.51 \\
13 & $1,5,23,37,35,32$ & Miscellaneous Manufacturing & 76 & 340 & 7.74 \\
14 & $45,46,47,49,55,58$ & Commerce and Transport & 94 & 335 & 7.63 \\
15 & $59,64,68,69,71-79$ & Other Services & 124 & 374 & 8.52 \\
16 & 61,62 & Software Development and & 79 & 273 & 6.22 \\
\hline
\end{tabular}

Table A2: Variable description

\begin{tabular}{|c|c|c|c|}
\hline Label & Unit & Description & Source \\
\hline$R \& D$ & million $€$ & annual R\&D expenditure & $\begin{array}{l}\text { OECD R\&D survey Flanders } \\
\text { provided by ECOOM } \\
\text { (K.U.Leuven) }\end{array}$ \\
\hline PATSTOCK & count & $\begin{array}{l}\text { discounted sum of patent } \\
\text { application since first observed } \\
\text { patent }\end{array}$ & European Patent Office \\
\hline PATAPPS & count & $\begin{array}{l}\text { sum of patent applications in a } \\
\text { given year }\end{array}$ & European Patent Office \\
\hline CITSTOCK & count & $\begin{array}{l}\text { discounted sum of patent citations } \\
\text { since first observed patent }\end{array}$ & European Patent Office \\
\hline CITATIONS & count & $\begin{array}{l}\text { sum of citations to patents in first } \\
\text { observed patent }\end{array}$ & European Patent Office \\
\hline WCAP & million $€$ & $\begin{array}{l}\text { book value cash }+ \text { inventories }+ \\
\text { accounts receivable - accounts } \\
\text { payable }\end{array}$ & $\begin{array}{l}\text { Bureau van Dijk BEL-FIRST } \\
\text { database }\end{array}$ \\
\hline DEBT & million $€$ & book value of liabilities & Bureau van Dijk BEL-FIRST \\
\hline & million $€$ & book value of tangible assets & Bureau van Dijk BEL-FIRST \\
\hline EMP & headcount & $\begin{array}{l}\text { number of dependent employees } \\
\text { in a given year }\end{array}$ & $\begin{array}{l}\text { Bureau van Dijk BEL-FIRST and } \\
\text { OECD R\&D survey }\end{array}$ \\
\hline AGE & years & survey year minus founding year & $\begin{array}{l}\text { Bureau van Dijk BEL-FIRST } \\
\text { and OECD R\&D survey }\end{array}$ \\
\hline GROUP & {$[0,1]$} & $\begin{array}{l}\text { Survey question on group } \\
\text { structure }\end{array}$ & OECD R\&D survey Flanders \\
\hline
\end{tabular}

Note: year and industry dummies not presented. Year refers to the reference year of the corresponding survey and the industry definition stems from the survey and has been crosschecked with the BEL-FIRST Database. It refers to the company's main activity. 